\title{
Episiotomy Vs Perineal Tear -A Comparative Study Of Maternal and Fetal Outcome
}

\author{
Dr Rumi Bhattacharjee, M.D. \\ Obst\& Gynae, Assistant Prof.,Dept. of Obst.\&Gynae,Pramukh Swami Medi
}

\section{Introduction}

An episiotomy is a surgical incision that is made in the perineum between the vagina and anus and is intended to expedite delivery of the fetus. It was believed that episiotomies healed better and had fewer complications such as dyspareunia or incontinence than spontaneous tears.

Episiotomy was $1^{\text {st }}$ introduced in the eighteenth century. Earlier, perineal care emphasized on soothing and supporting the perineum during childbirth as evident in the writings of Ephedus in the treatise 'Gynecology' $(98-138) \mathrm{AD}{ }^{(1,2)}$. During the $11^{\text {th }}$ century, a series of work was published from the $1^{\text {st }}$ medical school at Salerno, Italy. They all emphasized on protecting and preserving the perineum and cried against genital trauma ${ }^{(3)}$.

Episiotomy was first described by Sir Fielding Ould in 1742 and in another 100 years it had become a commonly accepted practice. It was first published in a medical journal in $1810^{(4)}$.

Episiotomy and other surgical interventions were incorporated into obstetric practice with the advent of the male birth attendants. The rise in episiotomies also coincided with the shift from home deliveries to hospital deliveries.

The use of episiotomy had become routine and unquestioned from 1940 to1980, when Kitzinger and others in 1981 expressed doubts regarding its effectiveness and the first randomized studies were undertaken by Sheep and colleagues in $1984^{(5)}$.

Current evidence now shows that episiotomy increases the risk of $3^{\text {rd }}$ and $4^{\text {th }}$ degree tears, wound infections, PPH and does not prevent long term complications such as perineal pain or urinary incontinence.

The Argentine Episiotomy Trial Collaboration Group reported that episiotomy rates $>30 \%$ in multigravidas and $>40 \%$ in primigravidas cannot be justified ${ }^{(6)}$.

\section{Aims And Objecives-}

The present study aims to compare maternal and fetal outcome in women receiving episiotomy versus women with tears and whether tears have benefit over routine episiotomy with regards to the intraoperative, early and late postoperative course.

\section{Methods And Materials-}

A two arm observational study was conducted in the obstetric \& gynecology department of Bombay hospital during the period $1^{\text {st }}$ December 2011 to $30^{\text {th }}$ May 2012

One arm consisted of 111 women who received episiotomy (control group)

The other arm consisted of 38 women who had tears (study group).

Inclusion criteria - Primiparous and multiparous women at term pregnancy with no obstetric complication.

-Instrumental deliveries were included.

Exclusion criteria- multiple pregnancies

- Malpresentation

-Preterm labour

-Previous surgery on the reproductive tract.

Episiotomies were given routinely or for fetal distress and prolonged second stage.

Detailed history, examination and routine investigations were carried out. Informed consent was taken from each patient.

Data regarding age of mothers, parity, and gestational age, type of delivery, intrapartum complications, post partum morbidities and fetal outcome were analyzed.

The outcome measures noted were-

1 Blood loss.

2 Early post partum pain on day 7

3 Late post partum pain on follow up at third month

4 Sexual discomforts.

5 Urinary/ bowel incontinence.

6 Fetal outcomes. 
Post operative pain was assessed by $10 \mathrm{~cm}$ long visual analog scale- VAS (no pain=0), (worst pain=10).Analgesics in the form of paracetamol 500mg TDS was given on day 1 and then on demand.

Statistical analysis was done using unpaired $t$ test and Fischer test where applicable.

\section{Results And Observations}

Table 1 Patient characteristics

Epi-

\begin{tabular}{|lcc|lccc|lcc|}
\hline $\begin{array}{l}\text { Age } \\
\text { (years) }\end{array}$ & Tear & Epi & Parity & Tear & Epi & $\begin{array}{l}\text { Gest } \\
\text { Age } \\
\text { (weeks) }\end{array}$ & Tear & Epi \\
\hline$<20$ & & 2 & 0 & 21 & 67 & $36-37.6$ & 11 & 40 \\
\hline $20-30$ & 28 & 82 & 1 & 13 & 39 & $38-39.6$ & 26 & 68 \\
\hline $30-40$ & 10 & 27 & 2 & 4 & 5 & & $>40$ & 1 & 3 \\
\hline
\end{tabular}

Episiotomy

Gest- Gestational

Table 2 Mode of delivery

\begin{tabular}{|c|c|c|c|c|c|c|c|c|}
\hline $\begin{array}{l}\text { Total } \\
\text { deliveries } \\
(\mathrm{N})\end{array}$ & $L S C S$ & \multicolumn{3}{|c|}{$\begin{array}{l}\text { Spontaneous vaginal } \\
\text { deliveries } \\
\qquad \mathrm{N}-130\end{array}$} & \multicolumn{3}{|c|}{$\begin{array}{l}\text { Instrumental deliveries } \\
\quad \mathrm{N}-23\end{array}$} & \multirow[t]{2}{*}{$\begin{array}{r}\text { Others } \\
(N)\end{array}$} \\
\hline 302 & 149 & & & $\begin{array}{r}\text { Intact } \\
\text { perineum }\end{array}$ & Tear & & $\begin{array}{c}\text { Epi } \\
+ \\
\text { tear }\end{array}$ & \\
\hline & & 35 & 91 & 4 & 3 & 12 & 8 & \\
\hline
\end{tabular}

Table 3 Distribution of subjects and controls

\begin{tabular}{|l|c|c|c|}
\hline & Primiparous & Multiparous & Total \\
\hline Tear & 19 & 19 & 38 \\
\hline Episiotomy & 60 & 33 & 93 \\
\hline Intact perineum & 3 & 1 & 4 \\
\hline $\begin{array}{l}\text { Tear with } \\
\text { episiotomy }\end{array}$ & 16 & 2 & 18 \\
\hline
\end{tabular}

Table 4 Outcome Data In Terms Of Intraoperative \& Postoperative Course

\begin{tabular}{|c|c|c|c|c|c|}
\hline & $\begin{array}{l}\text { Spontaneous tear } \\
\mathrm{N}-38 \\
\end{array}$ & $\%$ & $\begin{array}{c}\text { Episiotomy } \\
\mathrm{N}-111 \\
\end{array}$ & $\%$ & P Value \\
\hline $\begin{array}{l}\text { Blood } \\
\text { Loss }>500 \mathrm{ml}\end{array}$ & 2 & 5.2 & 10 & 9 & $\begin{array}{l}0.73(\mathrm{NS}) \\
\text { Fischer's } \\
\text { Test }\end{array}$ \\
\hline $\begin{array}{l}\text { Severe perineal } \\
\text { Injury }(\mathrm{N})\end{array}$ & 4 & 10.5 & 10 & 9 & $\begin{array}{l}0.75 \text { (NS) } \\
\text { Fischer's } \\
\text { Test }\end{array}$ \\
\hline $\begin{array}{l}\text { Time taken to } \\
\text { Suture (minutes) } \\
\text { Mean } \pm \text { SD }\end{array}$ & $\begin{array}{c}25.13 \\
25.13 \pm 9.75\end{array}$ & & $\begin{array}{c}24.34 \\
24.34 \pm 10.26\end{array}$ & & $\begin{array}{l}>0.05(\mathrm{NS}) \\
\text { Fischer's } \\
\text { Test }\end{array}$ \\
\hline $\begin{array}{l}\text { Early perineal pain score } \\
\text { Mean } \pm \text { SD }\end{array}$ & $\begin{array}{c}2.368 \\
2.37 \pm 1.65\end{array}$ & & $\begin{array}{c}4.736 \\
4.84 \pm 1.92\end{array}$ & & $\begin{array}{l}<0.0001 \\
(\mathrm{Sig}) \\
\mathrm{CI}(3.16 \text { to } \\
1.78) \\
\text { Unpaired } \\
\text { t test }\end{array}$ \\
\hline $\begin{array}{l}\text { Late perineal } \\
\text { Pain score } \\
\text { Mean } \pm \text { SD }\end{array}$ & $\begin{array}{c}0.1 \\
0.11 \pm 0.31\end{array}$ & & $\begin{array}{c}1.1 \\
1.19 \pm 0.87\end{array}$ & & $\begin{array}{l}<0.0001 \\
(\text { Sig) } \\
\text { t test }\end{array}$ \\
\hline
\end{tabular}


Continued

\begin{tabular}{|c|c|c|c|c|c|}
\hline Fever & 1 & 2.6 & 3 & 2.7 & $\begin{array}{l}1.00(\mathrm{NS}) \\
\text { Fischer's test }\end{array}$ \\
\hline Wound infection & 0 & & 0 & & - \\
\hline Wound dehiscence & 0 & 0 & 1 & 0.9 & $\begin{array}{l}1.000(\mathrm{NS}) \\
\text { Fischer's test }\end{array}$ \\
\hline $\begin{array}{l}\text { Average hospital stay (days) } \\
\text { Mean } \pm \text { SD }\end{array}$ & $\begin{array}{c}2.1 \\
2.16 \pm 0.68\end{array}$ & & $\begin{array}{c}3 \\
3 \pm 0.91\end{array}$ & & $\begin{array}{l}<0.0001 \\
(\mathrm{Sig}) \\
\mathrm{CI}(-1.16 \text { to }-0.52) \\
\mathrm{t} \text { test }\end{array}$ \\
\hline Bladder incontinence $(\mathrm{N})$ & 0 & 0 & 0 & 0 & - \\
\hline Bowel incontinence $(\mathrm{N})$ & 0 & 0 & 0 & 0 & - \\
\hline $\begin{array}{l}\text { Sexual discomfort } \\
(\mathrm{N})\end{array}$ & 1 & 2.6 & 8 & 7.2 & $\begin{array}{l}0.448(\mathrm{NS}) \\
\text { Fischer's test }\end{array}$ \\
\hline
\end{tabular}

Table-5Fetal outcome

\begin{tabular}{|c|c|c|c|c|c|}
\hline \multirow{2}{*}{ Outcome } & \multicolumn{2}{|c|}{ Spontaneous tear } & \multicolumn{2}{|c|}{ Episiotomy } & \multirow[t]{2}{*}{$P$-Value } \\
\hline & $\mathbf{N}$ & $\%$ & $\mathbf{N}$ & $\%$ & \\
\hline $\begin{array}{l}\text { Apgar score }<7 \text { at } \\
5 \text { minutes }(\mathrm{N})\end{array}$ & 1 & 2.6 & 3 & 2.7 & $\begin{array}{l}1.00(\mathrm{NS}) \\
\text { Fischer's test }\end{array}$ \\
\hline $\begin{array}{l}\text { NICU Admission } \\
(\mathrm{N})\end{array}$ & 4 & 10.5 & 8 & 7.2 & $\begin{array}{l}0.5(\mathrm{NS}) \\
\text { Fischer's test }\end{array}$ \\
\hline $\begin{array}{l}\text { Respiratory distress } \\
(\mathrm{N})\end{array}$ & 1 & 2.6 & 3 & 2.7 & $\begin{array}{l}1.00(\mathrm{NS}) \\
\text { Fischer's test }\end{array}$ \\
\hline
\end{tabular}

NS - Not Significant ; Sig - Significant

Table 1 shows that majority of patients in both groups were in age groups (20-30) yrs and gestational periods between (38-39.6) wks. Primiparous women constituted maximum no of patients in both groups.

The total no of deliveries during this 6 month study period was 302. One hundred and fifty three women were enrolled in the study. One hundred and eleven women underwent routine episiotomy and formed the control group. The study group included 38 women who had spontaneous tears. Four women had intact perineum and were excluded from study. The no of women where episiotomy was withheld was 42 . In the control group, 18 women had additional tears besides episiotomies in the form of contra lateral $1^{\text {st }}$ or $2^{\text {nd }}$ degree tears, extension of episiotomy, third or fourth degree tears. The no of instrumental deliveries was 23. Routine episiotomy was done in 20 women in this subgroup; out of which 8 women suffered additional tears.

The outcome data is shown in table 4. The blood loss was more in the control group. Severe perineal injury in the form of $3^{\text {rd }}$ and $4^{\text {th }}$ degree tears were $10.5 \%$ in the study group and $9 \%$ in the control group. The incidence of $3^{\text {rd }}$ and $4^{\text {th }}$ degree tears were more in our study due to inclusion of instrumental deliveries. Time taken to suture and post partum fever rates was similar in both groups. Both early and late post operative perineal pain were significantly less in the study group compared with the control group. This was also proved statistically. Early perineal pain ( $\mathrm{P}$ value $<0.0001$. Confidence Interval 3.16 to 1.78$)$ and late perineal pain $(\mathrm{P}<$ 0.0001 . Confidence Interval -1.37 to -0.80 ). None of the women in either group developed bladder/bowel incontinence. One woman in the study group had difficulty in sexual intercourse while 8 women in the control group gave similar history. The average hospital stay was slightly less in the study group. There was no significant difference between the two groups in respect to neonatal outcome except that NICU admissions were slightly more in the study group.

\section{Discussion}

The incidence of episiotomy in our study was $72.5 \%$. The incidence varies in different parts of the globe. The RCOG gives incidence of episiotomy as $8 \%$ in Holland, $14 \%$ in England, $50 \%$ in U.S.A. and $95 \%$ in Eastern Europe (March 2007). According to J. Reproductive Medicine 2006, the incidence of episiotomy in India is $95 \%$. It is particularly high in private sector hospitals (91.8) and tertiary care set up (80.7\%).

Physicians have a greater trend of performing episiotomies than midwifes.

The decision to perform episiotomy may be influenced by several factors such as non assuring FHS, instrumental deliveries, practitioner s preference and training. Physicians performing episiotomy believed that it decreased $3^{\text {rd }}$ and $4^{\text {th }}$ degree perineal tears, preserved the muscles of pelvic floor, accelerated healing and protected against fetal asphyxia \& trauma. However, it has been found by Thacker \& Banta; who reviewed data from 1860-1980, that the routine use of episiotomy was unjustified and had no additional benefits, rather resulted in increased blood loss, perineal laceration \& dyspareunia. 
Episiotomy is equivalent to second degree tear and studies indicate that episiotomy may decrease the incidence of anterior tears, but not posterior tears, rather may be associated with increased risk of $3^{\text {rd }} \& 4^{\text {th }}$ degree perineal tears ${ }^{(7,8)}$. In a study conducted by F.C.R. Williams et al, it was found that the rate of $3^{\text {rd }}$ degree tear was 5 times higher in women with episiotomy as compared to tear ${ }^{(6)}$. In this study, the statistical difference in this respect was insignificant. Ann M. Weber, in her study found that anal sphincter lacerations occurred in $8.3 \%$ of women with episiotomies vs. $3.8 \%$ of women without episiotomies ${ }^{(9)}$.

According to data collected by Hartmann \& colleagues between 1950 \& 2004, women with episiotomies experienced more pain and were more likely to have extensions during delivery. They were 2 times more likely to have fecal incontinence during $1^{\text {st }}$ five months of delivery. They also had $53 \%$ more incidence of sexual discomfort, 3 months postpartum ${ }^{(10)}$. In our study, the average pain score in the control group was (4.7early) and (1.1-late), while that in the study group was (2.3-early) and (0.1-late) which was much less. $2.6 \%$ experienced sexual discomfort in the study as against $7.2 \%$ in the control group.

However, there was no incidence of bladder/bowel injury in our study. In this study, $9 \%$ women in the control group had more blood loss as compared to $5.2 \%$ women in the study group. Similar observations have been made by other authors. According to Ma cleod M, et al, episiotomy is associated with high PPH (28.5vs $18.4)$, need for moderate to strong analgesia (90.5vs 67.6), perineal infection ( $5 \%$ vs $1.4 \%$ ) and neonatal trauma $(38 \% \mathrm{vs} 22 \%)^{(11)}$. In our study, one woman in the control group had wound dehiscence, while the neonatal outcomes were comparable in both groups.

According to the Cochrane Review 2009, the use of restrictive episiotomy decreased the risk of relevant morbidities such as posterior perineal trauma (RR $0.88,95 \% \mathrm{CI} 0.84$ to 0.92 ); need for suturing (RR $0.74,95 \%$ CI $0.71-0.77$ ) \& healing complications at 7 days (RR $0.69,95 \%$ CI 0.56 to 0.88 ). No difference in major outcomes such as severe vaginal \& perineal trauma or pain, dyspareunea and urinary incontinence was mentioned ${ }^{(12)}$.

The practice of episiotomy has been handed down by tradition over the decades and continues to be prevalent even after its effectiveness has been questioned by research. Episiotomy can be avoided by adopting certain measures before and after delivery such as - good nutrition, kegels exercise, and prenatal perineal massage to increase its elasticity, a slowed controlled $2^{\text {nd }}$ stage, warm compress $\&$ support during delivery.

\section{Conclusion}

The incidence of episiotomy has decreased from nearly 2 out of 3 vaginal births in 1979 to less than 1 in 5 in $2004^{(13)}$. Episiotomy only protects against anterior perineal tears, but does not provide protection against anal sphincter muscle tears, pelvic muscle damage or incontinence in the mother, nor does it prevent neonatal complications. Women who undergo episiotomy have more blood loss, delayed wound healing and more pain after childbirth.

\section{REFERENCES:}

[1]. Carter E, During T. With child birth through the ages, Edinburgh: Mainstream publishing company, 1986.

[2]. Temkin O, Soranus' Gynecology. Baltimore. The John Hopkins University Press; 1956.

[3]. O, Dowd M J. Phillipp E.The history of Obstetric \& Gynecology. New York. The Parthenox Publishing Group Inc; 2000.

[4]. David M. [Who invented the episiotomy? On the history of the episiotomy [.Zenthralbl Gynakol]. 1993; 115 (4): 188-93. German.

[5]. Kitzinger S. Simkin P. Episiotomy and the $2^{\text {nd }}$ stage of labour. $2^{\text {nd }}$ ed. Seattle: Penny Press Inc; 1984.

[6]. F. L R. Williams, C. du V. Florey, G. J. Mires and S. A. Ogston Episiotomy and perineal tears in low-risk UK primigravidae Journal of Public Health Medicine Vol. 20, No. 4, pp. 422-427 Printed in Great Britain

[7]. Smith MA, Ruffin MT, Green LA. The rational management of labor. Am Fam Physician 1993; 47: 1471-1481

[8]. Walker MPR, Farine D, Rolbin SH, Ritchie JWK. Epidural anesthesia, episiotomy, and obstetric laceration. Obstet Gynecol 1991; 77: 668-671.

[9]. Anne M. Weber, Leslie Meyn Episiotomy Use in the United States, 1979-1997 Obstetrics and Gynecology 2002; 100:1177-1182.

[10]. Katherine Hartmann, MD, PhD; Meera Viswanathan, PhD; Rachel Palmieri, BS; Gerald Gartlehner, MD, MPH; John Thorp, Jr, MD; Kathleen N. Lohr, PhD Outcomes of Routine Episiotomy A systematic review.JAMA. 2005; 293:2141-2148.

[11]. Ma Carthur AJ, Incidence severity \& determinants of perineal pain after vaginal delivery, a prospective cohort study. AM J Obst Gynecol, 2004; 191: 1199-1204.

[12]. Carroli G, Migninil, Episiotomy for vaginal birth. Cochrane Database of Systematic Reviews 2009. Issue 1, Art No. CD000081. DOI: $10,1002 / 14651858$.

[13]. Episiotomy Last updated Dec 2011. Baby Center Medical Advisory Board. 